$\begin{array}{ll}\text { Volume }: 06 \\ \text { Nomor } & : 03 \\ \text { Bulan } & : \text { September } 2020 \\ \text { Tahun } & : 2020 \\ \text { http } & : \text { //ejurnal.pps.ung.ac.id/index.php/Aksara }\end{array}$

\title{
Hubungan Power Otot Tungkai Dengan Kecepatan Tendangan Mawasi Geri Pada Mahasiswa Pendidikan Jasmani Kesehatan Dan Rekreasi (PJKR) Fakultas Olahraga dan Kesehatan Universitas Negeri Gorontalo
}

\author{
Ahmad Lamusu \\ Dosen Fakultas Olahraga dan Kesehatan Universitas Negeri Gorontalo \\ Ahmadlamusu2020@gmail.com \\ Zulkifli A. Lamusu \\ Dosen Fakultas Olahraga dan Kesehatan Universitas Negeri Gorontalo \\ harimullah.gorontalo@gmail.com
}

Received: 18 Juli 2020; Revised: 21 Agustus 2020; Accepted: 28 Agustus 2020 DOI: http://dx.doi.org/10.37905/aksara.6.3.365-376.2020

\begin{abstract}
ABSTRAK
Penelitian ini bertujuan untuk mengetahui Hubungan antara power otot tungkai dengan kecepatan tendangan mawasi geri pada mahasiswa Pendidikan Jasmani Olahraga Kesehatan Dan Rekreasi (PJKR) Fakultas Olahraga dan Kesehatan Universitas Negeri Gorontalo. Hipotesis dalam penelitian ini yakni "Terdapat Hubungan antara power otot tungkai dengan kecepatan tendangan mawasi geri pada mahasiswa Pendidikan Jasmani Olahraga Kesehatan Dan Rekreasi (PJKR) Fakultas Olahraga dan Kesehatan Universitas Negeri Gorontalo. Metode penelitian yang digunakan adalah metode Penelitian kuantitatif yang bersifat korelasi. Dengan desain terdiri atas 2 variabel penelitian yaitu Variabel X (Daya Ledak Otot Tungkai) dengan Variabel Y (Kecepatan tendangan mawasi geri), Adapun sampel dalam penelitian yang ditetapkan adalah sebanyak 20 mahasiswa Pendidikan Jasmani Olahraga Kesehatan Dan Rekreasi (PJKR) Fakultas Olahraga dan Kesehatan Universitas Negeri Gorontalo yang diambil secara Purfosive Sampling. Uji statistik yang digunakan untuk menguji hipotesis penelitian ini adalah uji korelasi, dan Dari hasil pengujian menunjukkan $r_{h i t u n g}(0,625)>r_{\text {tabel }}(444)$. Jadi ada hubungan variabel bebas dengan variabel terikatnya adalah signifikan. Dari data tersebut dapat menjawab hipotesis bahwa ada Hubungan antara power otot tungkai dengan kecepatan tendangan mawasi geri pada mahasiswa Pendidikan Jasmani Olahraga Kesehatan Dan Rekreasi (PJKR) Fakultas Olahraga dan Kesehatan Universitas Negeri Gorontalo.
\end{abstract}

Kata Kunci : Power Otot Tungkai, Tendangan Mawasi Geri

\section{PENDAHULUAN}

Karate merupakan salah satu bela diri dari jepang yang memiliki tujuan untuk pertahanan diri. Dalam bela diri ini banyak teknik-teknik khusus yang dipelajari sebagai bentuk pertahanan dan penyerangan, beberapa teknik dasar yang dipelajari dalam karate yaitu teknik dasar pukulan (tsuki), tendangan (geri), tangkisan (uke) dan kuda-kuda (dachi). Khususnya teknik dasar tendangan atau geri, untuk mempelajari dan melatih teknik ini agar mudah di kuasai maka awal mula yang perlu dipahami seorang kohai atau seorang karateka pemula adalah kecepatan dan keseimbangan, apabila dua hal ini sangat 


$\begin{array}{ll}\text { Volume } & : 06 \\ \text { Nomor } & : 03 \\ \text { Bulan } & : \text { September } 2020 \\ \text { Tahun } & : 2020 \\ \text { http } & : / / \text { ejurnal.pps.ung.ac.id/index.php/Aksara }\end{array}$

diperhatikan oleh seorang pemula dalam belajar karate bahkan cenderung dilatihnya agar bisa dikuasai, maka akan memudahkannya dalam mempelajari teknik tendangan dengan baik dan benar.

Salah satu faktor yang memiliki peran dalam penguasaan kecepatan tendangan adalah daya ledak otot tungkai atau power otot tungkai. Power otot tungkai merupakan perpaduan antara unsur kecepatan maksimum dan kekuatan maksimum dari hasil kontraksi otot itu sendiri. Dengan demikian maka dalam menguasai teknik dasar tendangan pada bela diri karate, maka salah satu tolok ukurnya adalah kemampuan power otot tungkai.

Pada bela diri karate ada beberapa teknik dasar tendangan yang dipelajari antara lain yaitu teknik mawasi geri atau tendangan mawasi. Mawasi geri merupakan teknik menendang yang dilakukan dari arah samping dengan sasaran pada dua target yaitu bagian rusuk dan bagian kepala. Teknik tendangan ini dilakukan dengan dorongan lutut dan pinggul dari arah samping hingga kaki terayun dan melayang secepat mungkin menuju pada wilayah target, dan saat perkenaan punggung kaki pada target terdapat tekanan berupa kekuatan yang diakibatkan oleh efek power otot tungkai.

Universitas Negeri Gorontalo merupakan salah satu perguruan tinggi yang memiliki program studi Pendidikan Jasmani Kesehatan dan Rekreasi (PJKR) yang berada dalam naungan Fakultas Olahraga Dan Kesehatan. Pada program studi ini terdapat pada kurikulum perkuliahannya yaitu mata kuliah teori dan praktek karate. Mata kuliah dimaksud merupakan mata kuliah wajib. Dalam proses perkuliahan mahasiswa diupayakan sungguh-sungguh dalam mempelajari mata kuliah ini baik secara teori dan praktek. Dari keseluruhan mahasiswa yang mengikuti mata kuliah karate memiliki variasi kemampuan dan keterampilan beragam dan bervariasi. Dari hasil pengamatan penulis dalam perkuliahan karate, rata-rata mahasiswa kesulitan saat mempelajari teknik dasar tendangan khsusnya mawasi geri. Kesulitan mahasiswa dalam melakukan mawasi geri terletak pada kecepatan tendangannya. Sementara unsur kecepatan dalam mempelajari teknik dasar tendangan pada karate merupakan faktor yang sangat mempengaruhi penguasaan teknik dasar tendangan yang baik dan benar.

Dari uraian di atas maka penulis berasumsi bahwa kurangnya kecepatan mawasi geri mahasiswa diakibatkan oleh minimnya keseimbangan saat melakukan tendangan sehingga daya ledak otot tungkai kurang maksimal. Untuk itu penulis tertarik untuk mengadakan suatu penelitian korelasi dengan judul yaitu: Hubungan power otot tungkai dengan kecepatan tendangan mawasi geri pada mahasiswa Pendidikan Jasmani Kesehatan Dan Rekreasi (PJKR) Fakultas Olahraga dan Kesehatan Universitas Negeri Gorontalo

\section{TEORI}

\section{Hakikat Power Otot atau Daya Ledak Otot}

Power otot atau daya ledak otot merupakan salah satu komponen yang penting dalam kegiatan olahraga, karena dengan power atau daya ledak kemampuan seseorang memukul, melompat, berlari dapat diukur kemam. Power atau daya ledak juga dapat diartikan sebagai kemampuan untuk meraih suatu kekuatan setinggi mungkin dalam waktu yang tersingkat (Syafruddin, 2012). Di samping itu menurut Widiastuti (2015:16) bahwa power atau daya ledak merupakan gabungan antara kekuatan dan kecepatan atau pengerahan otot maksimum dengan kecepatan maksimum atau bisa dikatakan bahwa 


Volume : 06
Nomor $: 03$
Bulan $\quad:$ September 2020
Tahun
http 2020
$:$ //ejurnal.pps.ung.ac.id/index.php/Aksara

power atau daya ledak adalah kemampuan kerja otot dalam satuan waktu. Selaras dengan hal ini Ismaryati (2006) menjelaskan bahwa power atau daya ledak otot menyangkut kekuatan dan kecepatan kontraksi otot yang dinamis dan eksplosif serta melibatkan pengeluaran kekuatan otot yang maksimal dalam waktu yang secepat cepatnya. Hal yang sama dikemukakan oleh Sajoto (1988) bahwa daya ledak otot (muscular power) adalah kemampuan seorang untuk melakukan kekuatan maksimum, dengan usaha yang dikerahkan dalam waktu yang sependek-pendeknya. Senada dengan apa yang dikemukakan Sajoto, Bompa (2009: 233) menegaskan bahwa power adalah hasil dari dua kemampuan yaitu kecepatan maksimal dan kekuatan maksimal dalam waktu yang sesingkat mungkin. Dengan kata lain bahwa setiap gerakan tubuh dalam olahraga pada hakikatnya disebabkan berkontraksinya otot-otot rangka untuk mengatasi beban atau hambatan berupa berat tubuh sendiri seperti gerakan melompat yang melibatkan komponen dari otot tungkai (Ayu Widi Muchlisa, 2017:04).

Dari penjelasan di atas maka dapat disimpulkan bahwa power otot atau daya ledak otot memiliki peran yang berbeda ditinjau dari aktivitas olahraga yang dilakukan. Menurut Bompa (1994) bahwa power otot atau daya ledak otot jika dilihat dari sifat karakteristik cabang olahraga maka dapat diklasifikasi dua macam yaitu power atau daya ledak siklik dan daya ledak asiklik. Daya ledak siklik diperlukan pada cabang olahraga yang memerlukan gerakan yang berulang-ulang atau yang mengulang siklus, misalnya pada lari, renang dan balap sepeda. Sedangkan power atau daya ledak asiklik adalah gerak yang kuat dan cepat dalam satu gerakan seperti bela diri (menendang dan memukul), gerakan pada tolak peluru, lempar lembing. Dengan demikian gerakan menendang bola adalah termasuk dalam daya ledak asiklik.

Berdasarkan ulasan-ulasan teori di atas maka dapat disimplukan bahwa terdapat dua unsur yang penting dalam power atau daya ledak, yaitu (1) kekuatan otot dan (2) kecepatan otot, dalam mengarahkan tenaga maksimal untuk mengatasi hambatan. Dengan demikian maka power otot atau daya ledak otot merupakan perpaduan atau kombinasi antara kekuatan dan kecepatan yang mengatasi beban atau tahanan dengan kecepatan kontraksi otot yang tinggi. Untuk itu jelaslah bahwa power atau daya ledak mengandung unsur kekuatan dan kecepatan. Kekuatan mengambarkan kemampuan otot untuk mengatasi beban atau tahanan.

\section{Peran Power Atau Daya Ledak Otot Tungkai Pada Olahraga Bela Diri}

Berbagai cabang olahraga memerlukan power otot atau daya ledak otot tungkai dalam penampilannya, terutama cabang-cabang olahraga yang membutuhkan kekuatan dan kecepatan dalam bereaksi, sebagai contoh cabang olahraga atletik, hampir semua nomor dalam cabang ini memerlukan daya ledak, mulai dari nomor lari, lompat maupun lempar dan berbagai cabang olahraga permainan. Selain itu, dalam cabang beladiri juga diperlukan power atau daya ledak terutama pada saat melakukan tendangan dan gerakangerakan lain yang melibatkan kerja otot tungkai yang dikerahkan secara maksimal dalam waktu yang singkat seperti cabang olahraga beladiri.

Pada cabang olahraga beladiri di dalamnya terdapat gerakan melompat, menendang dan gerakan-gerakan lain yang melibatkan kerja otot tungkai. Dengan demikian maka agar bisa mempelajari teknik dasar pada bela diri dengan mudah maka seorang harus memiliki daya ledak otot tungkai yang baik. Hal ini seperti yang dikemukakan oleh Jonath, Haag \& Krempel dalam Syafruddin (2011:19) bahwa prestasi 


\begin{tabular}{|c|c|c|}
\hline & \multirow{2}{*}{\multicolumn{2}{|c|}{ Volume : 06}} \\
\hline & & \\
\hline & Nomor & $: 03$ \\
\hline & Bulan & : September 2020 \\
\hline & $\begin{array}{l}\text { Tahun } \\
\text { http }\end{array}$ & $\begin{array}{l}\text { : } 2020 \\
\text { : //ejurnal.pps.ung.ac.id/index.php/Aksara }\end{array}$ \\
\hline
\end{tabular}

bergantung pada tenaga otot tungkai dan latihan eksplosifitas dapat memperbaiki kecepatan, pengembangan tenaga dan keduanya itu sangat perlu bagi prestasi yang baik.

Menurut Rosmawati dkk (2019:46) bahwa power atau daya ledak otot tungkai adalah kemampuan otot untuk mengatasi beban dan tahanan dengan kecepatan kontraksi yang sangat tinggi hal ini terjadi karena pada daya ledak otot tungkai terdapat gabungan dari dua kemampuan yaitu kekuatan (strength) dan kecepatan (speed), dimana kekuatan dan kecepatan dikerahkan maksimum dalam waktu yang sangat cepat dan singkat. Untuk itu dalam cabang oahraga bela diri kontribusi daya ledak otot tungkai sangat berarti khususnya pada teknik menendang. Karena pada waktu melakukan tendangan terjadi gabungan dari kekuatan otot tungkai paha atas dan otot tungkai bawah saat berkontraksi.

Menurut Sepriadi (2018:33) bahwa tungkai bawah mempunyai tugas yang sangat penting untuk melakukan gerak, gerakan tersebut dapat dilakukan dengan adanya suatu sistem penggerak, yang meliputi otot dan tulang yang terjadi akibat berkontraksinya otototot rangka dan saling kerja sama dari sistem rangka dan otot manusia, termasuk sistem persarafan. Dengan demiian maka dapat dikatakan bahwa daya ledak otot tungkai merupakan kemampuan otot atau sekelompok otot tungkai dalam mengatasi tahanan beban atau dengan kecepatan tinggi dalam satu gerakan yang utuh.

\section{Hakikat Kecepatan}

Kecepatan merupakan salah satu elemen kondisi fisik yang sangat penting dalam banyak cabang olahraga. Dalam banyak literatur dijelaskan bahwa kecepatan salah satu elemen dasar dalam kondisi fisik. Sebagai elemen dasar, maka kecepatan berdiri sendiri. Berdiri sendiri artinya tidak dipengaruhi oleh elemen kondisi fisik yang lain. Dalam berbagai cabang olahraga, kecepatan memegang peranan penting dalam keberhasilan pencapaian prestasi karena kecepatan merupakan komponen fisik yang esensial. Menurut Nur Ihsan dan Suwirman (2018:02) bahwa kecepatan adalah kemampuan untuk melakukan gerakan-gerakan yang sejenisnya secara berturur-turut dalam waktu yang sesingkat-singkatnya, atau kemampuan untuk menempuh suatu jarak dalam waktu yang sesingkat-singkatnya. Kecepatan bukan hanya berarti menggerakkan seluruh tubuh dengan cepat, akan tetapi dapat pula terbatas pada menggerakkan anggota-anggota tubuh dalam waktu yang sesingkat-singkatnya.

Menurut Sajoto (dalam Johanna Matitaputty 2019:107), Kecepatan adalah kemampuan seseorang untuk mengerjakan gerakan yang berkesinambungan dalam bentuk yang sama dalam waktu yang sesingkat-singkatnya, selanjutnya Dikdiik Zafar (2010) mendefinisikan bahwa kecepatan adalah hasil kecepatan gerakan dari kontraksi otot secara cepat dan kuat (powerfull) melalui gerakan yang halus (smooth) dan efisien (efficient). Berdasarkan penjelasan di atas maka kecepatan dapat diartikan sebagai kemampuan seseorang untuk melakukan gerakan dalam waktu yang sesingkat singkatnya.

Hampir semua cabang olaraga yang dilakukan menuntut adanya unsur kecepatan dalam melakukan aktivitas. Konsep dasar kecepatan secara mekanis merupakan rasio antar jarak dan waktu, sehingga unsur kecepatan selalu berkaitan dengan waktu reaksi, frekuensi gerak dan kecepatan menempuh jarak tertentu. Sehingga jika ditinjau kembali maka dalam teori kecepatan mengandung pengertian kemampuan seseorang untuk melakukan gerak atau serangkai gerak dalam waktu yang sesingkat singkatnya sebagai reaksi dari suatu rangsangan. Mengamati uraian ini, maka menurut Menurut Sajoto 


Volume : 06
Nomor $: 03$
Bulan $\quad:$ September 2020
Tahun
http 2020
$:$ //ejurnal.pps.ung.ac.id/index.php/Aksara

(dalam Johanna Matitaputty 2019:108) terdapat dua jenis kecepatan yaitu kecepatan reaksi dan kecepatan gerak, kecepatan reaksi adalah kemampuan seseorang untuk bereaksi secepat mungkin terhadap rangsangan, sedangkan kecepatan gerak adalah kemampuan seseorang untuk melakukan gerak atau serangkaian gerak dalam waktu yang sesingkat mungkin.

Berdasarkan teori-teori yang telah dikemukakan di atas, maka dapat disimpulkan bahwa kecepatan merupakan kemampuan reaksi gerakan seseorang, yang terjadi secara singkat seperti berpindah tempat atau berupa reaksi gerak ditempat dalam merespon suatu gerakan tertentu.

\section{Hakikat Karate}

Karate merupakan suatu ilmu pengetahuan tentang bela diri dengan tangan kosong atau tanpa senjata. Namun demikian karate jangan hanya dipandang sebagai suatu keterampilan teknik pertarungan semata, karena pada hakikatnya karate memiliki makna jauh melebihi sekedar teknik membela diri. Menurut Sajoto, (2006) bahwa karate adalah suatu cara menjalankan kehidupan yang tujuannya adalah memberi kemungkinan bagi seseorang agar mampu menyadari daya potensi dirinya, baik secara fisik maupun yang berhubungan dengan segi mental dan spiritual. Kalau karate mengabaikan sisi spiritual, maka sisi fisik menjadi kurang bermakna.

Menurut Simanjuntak, (dalam Muhammad Iqbal Baramul dkk 2020:02) Karate adalah sebuah olahraga beladiri yang berasal dari negara Jepang, karate sendiri masuk ke Indonesia pada tahun 1966 oleh mahasiswa Indonesia yang belajar di Jepang, karate sendiri memiliki pengertian yang terdiri atas dua kanji, yang pertama adalah kara yang memiliki arti tangan dan te adalah kosong di mana ke dua kanji tersebut berarti tangan kosong. Hal ini senada dengan yang dikemukakan Dewi Nastiti, (2011:04) bahwa kata karate merupakan kombinasi dari dua karater kata jepang, kara berarti kosong dan te berarti tangan, oleh sebab itu karate dapat diartikan dengan tangan kosong, jika kata karate ditambah dengan akhiran do yang memiliki arti cara, maka perngertian karate-do menjadi penerapan karate sebagai cara hidup yang lebih dari sekedar mepertahankan diri. Dari dua pernyataan di atas, Muhammad Rhadian (2018:03) menambahkan bahwa biasanya penggunaan kata karate dikuti dengan kata do yang memilii arti seni bela diri menggunakan tangan kosong. Sementara menurut Bondhan Adi Pratomo (2013:17) bahwa karate merupakan seni bela diri yang dikembangkan di kpulauan Ryukyu (Okinawa) yang saat ini masuk dalam wilayah Jepang, secara harafiah karate berarti teknik pertahanan diri dengan tangan kosong, yang artinya bahwa fokus dari disiplin bela diri ini adalah gerakan-gerakan yang terdiri dari pukulan, tendangan, tangkisan, hantaman, pergulatan, kuncian dan bantingan dengan mengolah seluruh fungsi anggota tubuh menjadi senjata yang mematikan. Dari beberapa penjelasan tentang devinisi karate di atas, Witri Fandayani \& Sagitarius (2019:22) memiliki pandangan lebih mendalam tentang karate, menurutnya bahwa karate memiliki pengertian yang lebih khas yaitu sebagai seni bela diri tangan kosong yang digunakan untuk mengembangkan karakter melalui latihan sehingga seorang karateka tidak hanya mempelajari kekuatan fisik, namun juga mempelajari kekuatan mental, spiritual, dan kepribadian.

Dari beberapa ulasan di atas maka secara rinci dapat dikatakan bahwa karate merupakan suatu ilmu pengetahuan tentang bela diri dengan tangan kosong atau tanpa senjata. Namun demikian karate jangan hanya dipandang sebagai suatu keterampilan 


$\begin{array}{ll}\text { Volume }: 06 \\ \text { Nomor } & : 03 \\ \text { Bulan } & : \text { September } 2020 \\ \text { Tahun } & : 2020 \\ \text { http } & : / / \text { ejurnal.pps.ung.ac.id/index.php/Aksara }\end{array}$

teknik pertarungan semata, karena pada hakikatnya karate memiliki makna jauh melebihi sekedar teknik membela diri. Karate pada dasarnya dapat digambarkan sebagai sebuah sistem fisik pertahanan diri yang tidak bergantung pada penggunaan senjata. Karate adalah falsafah hidup yang berkembang melalui pelatihan fisik. Pelatihan fisik karate akan mencakup, peningkatan fungsi kardiovaskular, Kekuatan, Fleksibilitas, daya tahan otot, fisik koordinasi, mental konsentrasi, perbaikan memori dan kekuatan batin.

Berpijak dari teor-teori di atas maka dapat disimpulkan bahwa karate dapat diartikan sebagai seni beladiri dengan tangan kosong dengan falsafah hidup yang berkembang melalui Pelatihan fisik, pelatihan teknik-teknik dasar karate serta mental atau disiplin. Pelatihan fisik karate akan mencakup peningkatan sistem kardiovaskuler, kekuatan, kecepatan, daya tahan otot, kordinasi gerakan dan mental, oleh karana itu dalam usaha untuk mencapai prestasi pada cabang olahrag karate, faktor kondisi fisik, teknik dan mental perlu untuk dilatih secara sistimatis.

\section{Teknik Dasar Karate}

Sama halnya dengan olahraga bela diri lain, karate memiliki beberapa teknik dasar utama yang wajib dipelajari dan diketahui oleh setiap karatedo, adapun teknik dsar itu adalah Kihon (teknik dasar), Kata (jurus), dan Kumite (pertarungan). Di antara ketiga teknik utama tersebut yang menjadi kunci utama seseorang dalam belajar karate adalah kihon atau teknik dasar. Beberapa teknik dasar atau kihon dimaksud yaitu, teknik dachi (kuda-kuda), tsuki (pukulan), uke (tangkisan) geri (tendangan). Beberpaa teknik dasar yang telah disebutkan wajib untuk dipelajari dan dikuasai oleh seluruh karatedo, karena dalam setiap memulai untuk belajar atau latihan karate setiap karatedo baik dari tinggkatan kohai (murid), senpay (pelatih) hingga sensei (maha guru) wajib mengawali latihan mereka dengan kihon atau latihan tekanik dasar, karena kihon yang baik dan sempurnah akan menentukan kualitas latihan seorang karatedo. Hal ini seperti yang dikemukakan Wahid (2007), menurutnya bahwa kihon berarti pondasi, awal, akar dalam bahasa Jepang, sementara itu dalam karate sendiri kihon berarti sebagai bentuk-bentuk baku yang menjadi acuan dasar dari semua teknik atau gerakan yang mungkin dilakukan dalam kata maupun kumite.

\section{Teknik Dasar Tendangan Mawasi geri}

Geri atau tendangan merupakan salah satu teknik dasar pada bela diri karate. pada geri atau tendangan terbagi dalam beberapa teknik dasar utama yaitu tendangan may geri yaitu teknik tendagan yang dengan sasaran perut, kikomi yaitu tendangan sasaran wilayah rusuk dengan menggunakan bagian sisi kaki, mawasi geri yaitu tendangan yang arahakan pada bagian rusuk hingga leher maupun muka bagian rahang lawan dengan menggunakan punggung dan juga ujung kaki. Beberapa teknik dasdar tendangan di atas yang sering kali digunakan sebagai upaya mengecok atau memancing lawan agar bisa meluncurkan serangan adalah tendangan mawasi geri, dengan demikian tendangan ini perlu dilatih kecepatannya dengan tujuan untuk memaksimalkan teknik tendangan baik digunakan sebagai strategi memancing lawan maupun rangkaian serangan yang sesungguhnya.

Menurut Sutojo (1996 dalam Pangondian Hotliber Purba, 2017:49) bahwa hampir kira-kira $70 \%$ teknik karate menggunakan teknik tendangan, dan kekuatan tendangan kurang lebih lima kali lebih besar daripada kekuatan pukulan. Di antara teknik tendangan yang paling banyak digunakan adalah mawasi geri. Menurut Muhammad Iqbal Baramul 


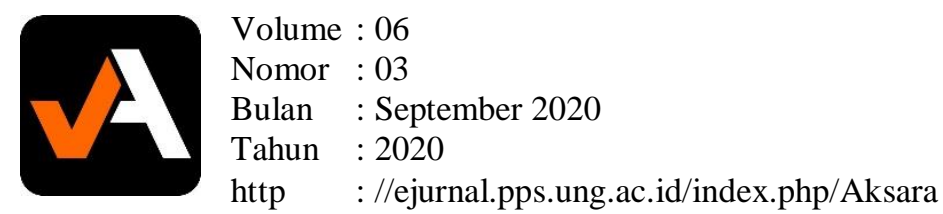

dkk (2020:02) bahwa tendangan mawasi geri merupakan teknik tendangan melingkar dengan target sekitar pinggang, untuk itu dalam membiasakan dan melancarkan teknik tendangan tersebut maka ada beberapa beberapa faktor penentu yang dibutuhkan demi maksimalnya tendangan dimaksud yaitu kecepatan, ketepatan dan konsentrasi tinggi guna mencapai sasaran tepat.

Dari penjelasan di atas maka dapat disimpulkan bahwa tendangan mawasi geri merupakan salah satu teknik dasar karate yang harus dipelajari dan dilatih dengan sungguh-sungguh oleh setiap karatedo khususnya bagi pemula. Adapun hal utama yang perlu diperhatikan dalam mempelajari dan berlatih teknik dasar tendangan mawasi geri adalah unsur kecepatan, karena hal dimaksud merupakan faktor pendukung terkuasainya teknik tendangan tersebut.

Jadi kecepatan tendangan mawasi geri merupakan kemampuan gerak yang diakibatkan oleh power otot atau daya ledak otot tungkai. Artinya bahwa semakin baik power otot tungkai seseorang maka unsur kecepatan tendangan mawasi geri lebih terbentuk dengan sempurna. Untuk itu antara power otot tungkai dengan kecepatan suatu gerakan tendangan merupakan perpaduan unsur gerak otot yang tidak dapat terpisahkan. Kecepatan merupakan unsur gerakan yang tercipta dimana terjadi adanya tekanan yang memiliki power atau daya ledak, artinya bahwa terjadinya unsur gerakan yang memiliki kecepatan yang sempurna disebabkan oleh semakin besarnya power otot tungkai seseorang.

\section{METODE PENELITIAN}

Metode yang digunakan dalam penelitian ini adalah metode korelasional dengan menggunakan pendekatan kuantitatif, Menurut Sugiono (2008:14) metode penelitian kuantitatif dapat diartikan sebagai metode penelitian yang melandaskan pada filsafat positivisme digunakan untuk meneliti pada populasi atau sampel tertentu, teknik pengambilan sampel pada umumnya dilakukan secara random pengumpulan data menggunakan instrumen penelitian analisis data, dengan demikian maka untuk menghasilkan data yang akurat dalam penelitian ini penulis akan mendeskripsikan mengenai hubungan daya ledak otot tungkai dengan kecepatan mawasi geri pada mahasiswa Pendidikan Jasmani Olahraga Kesehatan Dan Rekreasi (PJKR) Fakultas Olahraga dan Kesehatan Universitas Negeri Gorontalo.

\section{Rancangan Penelitian}

Penelitian ini merupakan penelitian kuantitatif yang bersifat korelasi, yaitu untuk mengungkapkan hubungan daya ledak otot tungkai terhadap Kecepatan tendangan mawasi geri. Rancangan yang digunakan dalam penelitian ini dapat di gambarkan sebagai berikut : 


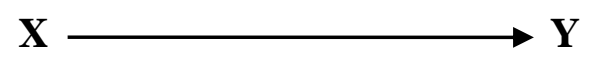

\section{Desain Penelitian}

Adapun desain penelitian ini sebagai berikut :

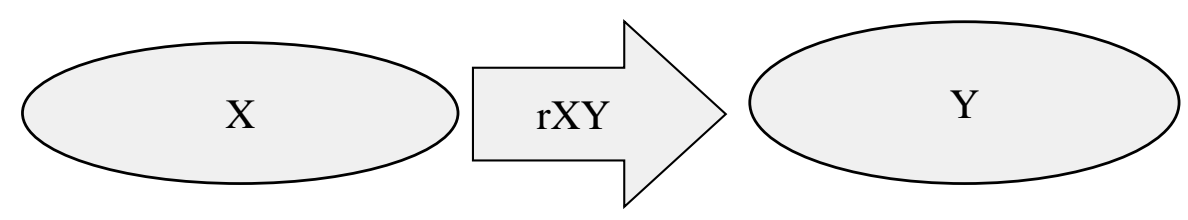

Dan untuk mencari koefisien korelasi digunakan rumus $r$ :

$$
r=\frac{\mathrm{n} \sum \mathrm{XY}-\left(\sum \mathrm{X}\right)\left(\sum \mathrm{Y}\right)}{\sqrt{\left[n \sum X^{2}-\left(\sum X\right)^{2}\right]\left[n \sum Y^{2}-\left(\sum Y\right)^{2}\right]}}
$$

\section{HASIL PENELITIAN}

Dalam penelitian ini, data yang dimaksud adalah data yang diperoleh dengan menggunakan metode korelasional dengan menggunakan pendekatan kuantitatif yakni mendeskripsikan mengenai hubungan power otot tungkai dengan dengan kecepatan tendangan mawasi geri pada mahasiswa Pendidikan Jasmani Olahraga Kesehatan Dan Rekreasi (PJKR) Fakultas Olahraga dan Kesehatan Universitas Negeri Gorontalo. Data dalam penelitian ini terdiri dua jenis tes, yaitu: (1) Mengukur power otot tungkai menggunakan Leg Dynamometer, (2) tes melakukan tendangan Mawasi Geri dalam waktu 10 detik.

Rangkuman Hasil Penelitian Power Otot Tungkai dan Tendangan Mawasi Geri

\begin{tabular}{|c|c|c|}
\hline Subjek & Power Otot Tungkai & Tendangan Mawasi Geri (T Score) \\
\hline 1 & 102.5 & 16 \\
\hline 2 & 45 & 15 \\
\hline 3 & 147 & 8 \\
\hline 4 & 120.5 & 15 \\
\hline 5 & 108 & 11 \\
\hline 6 & 64.5 & 12 \\
\hline 7 & 76.5 & 14 \\
\hline 8 & 59.5 & 11 \\
\hline 9 & 120 & 14 \\
\hline 10 & 124.5 & 19 \\
\hline 11 & 85 & 16 \\
\hline 12 & 68.5 & 11 \\
\hline 13 & 66 & 9 \\
\hline 14 & 104 & 9 \\
\hline 15 & 50 & 5 \\
\hline 16 & 62 & 9 \\
\hline 17 & 74.5 & 9 \\
\hline 18 & 116 & 8 \\
\hline 19 & 90.5 & 13 \\
\hline 20 & 70.5 & \\
\hline
\end{tabular}


Untuk membuktikan apakah ada Hubungan power otot tungkai dengan kecepatan tendangan mawasi geri pada mahasiswa Pendidikan Jasmani Olahraga Kesehatan Dan Rekreasi (PJKR) Fakultas Olahraga dan Kesehatan Universitas Negeri Gorontalo, perlu dilakukan pengujian hipotesis yang diajukan, maka untuk membuktikannya peneliti menggunakan rumus product moment sebagai berikut :

$$
r_{x y}=\frac{n \sum x_{i} y_{i}-\left(\sum x_{i}\right)\left(\sum y_{i}\right)}{\left.\sqrt{\left\{n \sum x_{i}{ }^{2}-\left(\sum x_{i}\right)^{2}\right)\left(n \sum y_{i}{ }^{2}-\left(\sum y_{i}\right)^{2}\right.}\right\}}
$$

Keterangan :

$\sum x y=$ Koefisien korelasi antara variabel $\mathrm{x}$ dan variabel $\mathrm{y}$

$\sum_{\mathrm{x}} \quad=$ Jumlah Seluruh Variabel $\mathrm{x}$

$\sum \mathrm{y} \quad=$ Jumlah Seluruh Variabel y

$\sum_{\mathrm{xy}} \quad=$ Jumlah Perkalian antara skor $\mathrm{x}$ dan skor $\mathrm{y}$

$\mathrm{N} \quad=$ Jumlah Sampel

$\sum \quad=$ Jumlah $($ Sigma $)$

Adapun data koefisien hubungan antara variabel $\mathrm{x}$ dengan variabel y pada mahasiswa Pendidikan Jasmani Olahraga Kesehatan Dan Rekreasi (PJKR) Fakultas Olahraga dan Kesehatan Universitas Negeri Gorontalo dapat dilihat pada tabel berikut.

Tabel 3 Hubungan Antara Variabel X Dengan Variabel Y

\begin{tabular}{|c|l|c|c|c|c|c|}
\hline No & \multicolumn{1}{|c|}{ Nama } & $\mathrm{x}$ & $\mathrm{y}$ & $\mathrm{x} 2$ & $\mathrm{y} 2$ & $\mathrm{xy}$ \\
\hline 1 & Andika S. Bengkal & 102.5 & 62.3529 & 10506.25 & 3887.88 & 6391.17 \\
\hline 2 & Fadel Mopangga & 45 & 50.5882 & 2025 & 2559.17 & 2276.47 \\
\hline 3 & Reinal Djuma & 147 & 59.4118 & 21609 & 3529.76 & 8733.53 \\
\hline 4 & Fikaryanto Abdulah & 120.5 & 38.8235 & 14520.25 & 1507.26 & 4678.23 \\
\hline 5 & Sahril Lasari & 108 & 59.4118 & 11664 & 3529.76 & 6416.47 \\
\hline 6 & Abdul R. Bilale & 64.5 & 47.6471 & 4160.25 & 2270.25 & 3073.24 \\
\hline 7 & Rioval Abdjul & 76.5 & 50.5882 & 5852.25 & 2559.17 & 3870 \\
\hline 8 & Ilham Yahya & 59.5 & 56.4706 & 3540.25 & 3188.93 & 3360 \\
\hline 9 & Abdul Haris M. & 120 & 47.6471 & 14400 & 2270.25 & 5717.65 \\
\hline 10 & Ramli & 124.5 & 56.4706 & 15500.25 & 3188.93 & 7030.59 \\
\hline 11 & Gufron & 85 & 71.1765 & 7225 & 5066.09 & 6050 \\
\hline 12 & Apriliyanto & 68.5 & 62.3529 & 4692.25 & 3887.88 & 4271.17 \\
\hline 13 & Rizal H. Hodio & 66 & 47.6471 & 4356 & 2270.25 & 3144.71 \\
\hline 14 & Muhajir & 104 & 41.7647 & 10816 & 1744.29 & 4343.53 \\
\hline 15 & Hendra Jenaan & 50 & 41.7647 & 2500 & 1744.29 & 2088.24 \\
\hline 16 & Rafli & 62 & 30 & 3844 & 900 & 1860 \\
\hline 17 & Sulfi R. Usman & 74.5 & 41.7647 & 5550.25 & 1744.29 & 3111.47 \\
\hline 18 & Nasarudin & 116 & 41.7647 & 13456 & 1744.29 & 4844.71 \\
\hline 19 & Rizki Tui & 90.5 & 38.8235 & 8190.25 & 1507.26 & 3513.53 \\
\hline 20 & Rizal Nasiki & 70.5 & 53.5294 & 4970.25 & 2865.4 & 3773.82 \\
\hline & Jumlah & 1755 & 1000 & 169377.5 & 51965.4 & 88548.5 \\
\hline & & & & & & \\
\hline
\end{tabular}




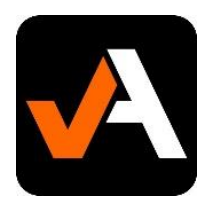

Volume : 06

Nomor : 03

Bulan : September 2020

Tahun : 2020

http : //ejurnal.pps.ung.ac.id/index.php/Aksara

Dengan melihat tabel kerja korelasi dengan jumlah responden 20 siswa maka diperoleh harga kritik r product moment pada taraf signifikan $5 \%$ adalah 0.404 , maka dapat diketahui :

$\begin{aligned} \mathrm{N} & =20 \\ \sum_{\mathrm{x}} & =1755 \\ \sum_{\mathrm{y}} & =1000 \\ \sum_{\mathrm{x}}{ }^{2} & =169377.5 \\ \sum_{\mathrm{y}}{ }^{2} & =51965.4 \\ \sum_{\mathrm{xy}} & =88548.5\end{aligned}$

Kemudian langkah selanjutnya adalah memasukkan jumlah nilai-nilai tersebut kedalam rumus korelasi product moment, yaitu :

$$
\begin{gathered}
r_{x y}=\frac{n \sum x_{i} y_{i}-\left(\sum x_{i}\right)\left(\sum y_{i}\right)}{\sqrt{\left\{n \sum x_{i}{ }^{2}-\left(\sum x_{i}\right)^{2}\right)\left\{n \sum y_{i}{ }^{2}-\left(\sum y_{i}\right)^{2}\right\}}} \\
=\frac{20(88548.5)-(1755)(1000)}{\sqrt{\{20(1755)-(169377.5)\}\{20(1000)-(51965.4)\}}} \\
=0.625
\end{gathered}
$$

\subsection{Pembahasan}

Penelitian ini bertujuan untuk mengetahui Hubungan antara power otot tungkai dengan kecepatan tendangan mawasi geri pada mahasiswa Pendidikan Jasmani Olahraga Kesehatan Dan Rekreasi (PJKR) Fakultas Olahraga dan Kesehatan Universitas Negeri Gorontalo. Data menunjukkan $r_{\text {hitung }}(0,625)>r_{\text {tabel }}(444)$. Jadi ada hubungan variabel bebas dengan variabel terikatnya adalah signifikan. Dari data tersebut dapat menjawab hipotesis bahwa ada Hubungan antara power otot tungkai dengan kecepatan tendangan mawasi geri pada mahasiswa Pendidikan Jasmani Olahraga Kesehatan Dan Rekreasi (PJKR) Fakultas Olahraga dan Kesehatan Universitas Negeri Gorontalo.

Berdasarkan hasil analisis menunjukkan ada Hubungan antara power otot tungkai dengan kecepatan tendangan mawasi geri. power otot tungkai memiliki peranan dalam menentukan kecepatan tendangan mawasi geri. Power atau daya ledak otot menyangkut kekuatan dan kecepatan kontraksi otot yang dinamis dan eksplosif serta melibatkan pengeluaran kekuatan otot yang maksimal dalam waktu yang secepat cepatnya.

Hasil tendangan yang baik selain didapatkan dari penguasaan teknik yang baik juga dipengaruhi oleh kondisi fisik yang baik pula, salah satunya adalah daya ledak (explosive power).

Gerakan utama pada sendi lutut adalah fleksi dan ekstensi tungkai bawah. Tetapi pada tungkai bawah dalam keadaan fleksi dapat pula dilakukan rotasi, sedang pada saat ekstensi rotasi tidak dapat dilakukan di sendi lutut. Bila sendi lutut berkembang normal, tungkai akan lurus (genu ractum) dengan garis beban berjalan melalui pertengahan caput femoris, pertengahan corpus femoris, pertengahan sendi lutut dan pertengahan calcaneus. Bila garis beban bergeser ke lateral yaitu berjalan melalui condylus femoris lateralis atau capitulum fibulae dikenal sebagai "genu valgum", maka ligamentum collaterale mediale akan teregang berlebih, sehingga lebih mudah cedera dan kaki akan berbentuk X. 


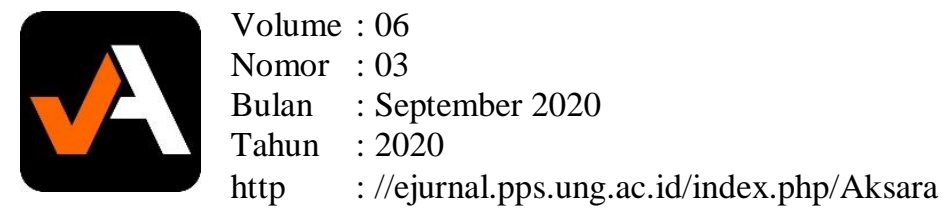

\section{PENUTUP \\ Simpulan}

Berdasarkan hasil analisis data, deskripsi, pengujian hasil penelitian, dan pembahasan, dapat disimpulkan bahwa: Ada hubungan yang signifikan antara power otot tungkai dengan kecepatan tendangan mawasi geri pada mahasiswa Pendidikan Jasmani Olahraga Kesehatan Dan Rekreasi (PJKR) Fakultas Olahraga dan Kesehatan Universitas Negeri Gorontalo. Data menunjukkan $r_{\text {hitung }}(0,625)>r_{\text {tabel }}(444)$. Jadi ada hubungan variabel bebas dengan variabel terikatnya adalah signifikan. Dari data tersebut dapat menjawab hipotesis bahwa ada Hubungan antara power otot tungkai dengan kecepatan tendangan mawasi geri pada mahasiswa Pendidikan Jasmani Olahraga Kesehatan Dan Rekreasi (PJKR) Fakultas Olahraga dan Kesehatan Universitas Negeri Gorontalo.

\section{Saran}

Berdasarkan kesimpulan hasil penelitian di atas, maka dapat dikemukakan saransaran sebagai berikut:

1. Untuk pelatih hendaknya memperhatikan faktor-faktor yang mempengaruhi penampilan atlet dalam melakukan tendangan mawasi geri.

2. Untuk pelatih harus selalu memperhatikan faktor-faktor yang mempengaruhi peningkatan prestasi melalui tendangan mawasi geri.

3. Untuk atlet perlu memperhatikan faktor-faktor yang mempengaruhi peningkatan latihan dalam melakukan tendangan mawasi geri.

4. Untuk pembaca diharapkan hasil penelitian ini dapat dijadikan sebagai sumber referensi dan bahan acuan untuk lebih memperluas lagi kajian mengenai kecepatan tendangan Mawasi Geri.

\section{DAFTAR PUSTAKA}

Ayu Widi Muchlisa. (2017). Jurnal Pendidikan Jasmani ISSN 0853-5043 (Pengaruh Koordinasi Mata Tangan Daya Ledak Otot Tungkai Dan Motivasi Berprestasi Terhadap Keterampilan Smash). Pascasarjana Universitas Negeri jakarta.

Ali Maksum. (2012). Metodologi Penelitian Dalam Olahraga. Surabaya: Universitas Surabaya.

Bondhan Adi Pratomo. 2013. Fundamental dan Filosofi Karate - Do. Surabaya. CV. Garuda Mas Sejahtera

Bompa, T. O. (2009). Theory And Methodologi of Training. IOWA: Kendal Hunt Pubhlishing Company.

Bompa \& Haff, G. (2009). Theori and Methodology Of Training. united State: Human Kinetics.

Dewi Nastiti, (2011), Menjadi Karateka. Jakarta : Be Champion.

Muhammad Rhadian. (2018). Karate. Bandung. PT. Indahjaya Adipratama

Nur Ihsan dan Suwirman. (2018). Sumbangan Konsentrasi terhadap Kecepatan Tendangan Pencak Silat. Fakultas Ilmu Keolahragaan. Universitas Negeri Padang. Jurnal Media Ilmu Keolahragaan Indonesia Volume 8. Nomor 1. p-ISSN 2088-6802 e-ISSN 2442-6830. 
Purba P.H. 2017.Hubungan Kelentukan Dan Kelincahan Terhadap Kecepatan Tendangan Mawashi Gery Chudan Pada Karateka Perguruan Wadokai Dojo Unimed. Jurnal Prestasi Vol. 1 No. 1, Juni 2017 : 11-16

Rosmawati, dkk. (2019) Hubungan Kelincahan Dan Daya Ledak Otot Tungkai Terhadap Kecepatan Tendangan Sabit Atlet Pencak Silat Silaturahmi Kalumbuk Kecamatan Kuranji Kota Padang. Universitas Negeri Padang. Jurnal Menssana, Volume 4, Nomor 1, Mei, ISSN 2527-6451 (Print), ISSN 2622-0295 (Online)

Sepriadi. (2018). Kontribusi Power Otot Tungkai dan Keseimbangan terhadap Tendangan Mawashi Geri Atlit Kempo. Fakultas Ilmu Keolahragaan. Universitas Negeri Padang. Jurnal Media Ilmu Keolahragaan Indonesia Volume 8. Nomor 2. p-ISSN 2088-6802 e-ISSN 2442-6830.

Sugiyono. (2011). Metode Penelitian Kuaantitatif, Kualitatif, dan R \& D. Bandung: Alfabeta.

Suharsimi Arikunto. (2010). Prosedur Penelitian Suatu pendekatan Praktek. Jakarta: Rineka Cipta.

Sujoto, J.B.(2006). Teknik Oyama Karate Seri Kihon. Jakarta: Elex Media Komputindo. Widiastuti. (2015). Tes dan Pengukuran Olahraga. Jakarta: RajaGrafindo persada 